\title{
Students’ Acceptance towards Entrepreneurship Module at Universiti Kebangsaan Malaysia
}

\author{
Mohamad Nurman Yaman, Mohammad Arif Kamarudin, Mohd Nasri Awang Besar, Siti \\ Mariam Bujang, Abdus Salam, Harlina Halizah Siraj, Nabishah Mohamad
}

Department of Medical Education, Universiti Kebangsaan Malaysia Medical Centre, Malaysia

$\begin{array}{ll}\text { ARTICLE INFO } \\ \text { Received } & : 13 / 09 / 2014 \\ \text { Accepted } & : 03 / 11 / 2014 \\ \text { Published } & : 01 / 12 / 2014\end{array}$

\section{KEYWORD}

Entrepreneurship

Soft Skills

Medical Students

Awareness

Curriculum

\section{ABSTRACT}

Introduction: Entrepreneurship CMIE 1022 module was introduced in February 2012 and was made compulsory to all first year undergraduate students in all faculties of Universiti Kebangsaan Malaysia (UKM). The main objective of CMIE 1022 is to expose the students to entrepreneurship with implementation of online teaching and business game simulation. Method: Module evaluation form was distributed among medical and nursing students at the end of the module. Result: One hundred seventyseven students responded to the survey with $50.3 \%$ of the respondents agreed that their soft skill have improved, 37.8\% for increased awareness of entrepreneurship, $25.6 \%$ has increased their interest in entrepreneurship and $22.22 \%$ agreed to apply in their own courses. More than three quarter of the students agreed that the lecturers and teaching assistants teaching methodology were acceptable. However, only $18.4 \%$ agreed that this course should be taken by all students of UKM. Conclusion: This study showed despite increase in soft skills and interests including high performance of the academics, most students disagreed on the introduction of CMIE 1022 course to all UKM students. It is suggested that the course curriculum to be reviewed in order to achieve the objectives.

(C) Medical Education Department, School of Medical Sciences, Universiti Sains Malaysia. All rights reserved.

CORRESPONDING AUTHOR: Full name: Dr Mohamad Nurman Yaman, Department of Medical Education, UKM Medical Centre, Bandar Tun Razak, 56000 Cheras, Kuala Lumpur. Email: mdnurman@gmail.com

\section{Introduction}

Entrepreneurship can be defined as the competency and readiness to develop, organize and manage a business endeavour (1). This can be combined with innovation and risk-taking and deemed to be an integral part of a nation's ability to thrive in ever challenging and increasingly competitive worldwide marketplace. Wahome et al agreed that in order for Malaysia to become a high-income nation to fulfill Malaysia Vision 2020, Malaysia has to change into a knowledgebased and innovative economy. In view of this, new workforce consisting of people of well grounded in science, engineering and technical vocations as well as in entrepreneurial skill must be produced and retained. Therefore entrepreneurial skill is considered as an important element in education in Malaysia. According to Malaysian Qualifications Agency, one of the eight domains of learning outcomes in Malaysian Qualifications Framework (MQF) of education is Managerial and Entrepreneurial Skills (3). 
In view of this recent development, Centre of Entrepreneurship and Small and Medium Enterprise Development (CESMED) of Universiti Kebangsaan Malaysia (UKM) have come out with a new teaching module named Basic Entrepreneurship and Innovation with a course code of CMIE 1022. The main objective of this course is to expose the students of UKM with entrepreneurial skill and to excite interest among the students to apply entrepreneurship skill in their future career.

The learning outcomes of this course are [1] to recognize of the basic concept in entrepreneurship; [2] describe the elements in entrepreneurship; [3] apply entrepreneurship knowledge through online business simulation game; [4] interpret the outcome of the business simulation game, and; [5] perform presentation in order to convince investor to invest into the course.

This course involves contact with CESMED fellows, online lectures, online quizzes, presentations, common lecture and online business simulation game. This CMIE 1022 course has been introduced to all first year undergraduate students in all faculties in UKM. Therefore, CESMED fellows are appointed among the lecturers in all faculties according to the number of students. These fellows were assisted by teaching assistants provided by the Faculty of Economics and Management. The common lectures were given by prominent entrepreneurs in Malaysia and were held in Tun Abdul Razak Chancellery Hall in UKM Main Campus in Bangi as well as being shown via direct telecast to UKM Kuala Lumpur Campus, UKM Medical Centre and Allianze University College Medical College (AUCMS) in Kepala Batas. The content of the online lectures, online quizzes and online business simulation game were provided by Stevens Institute of Technology (SIT). These online lectures provided were marketing, strategy, oral presentation, financial, production and teaming modules. The quizzes were conducted after each module where the students had to answer and submitted the answers online.
This study is to evaluate the CMIE 1022 course among the first year medical and nursing students in the Faculty of Medicine, UKM Medical Centre, mainly looking at the students' acceptance towards the module, bearing in mind as this is the first entrepreneurship course to be conducted compulsorily to the medical students in Malaysia (4).

\section{Method}

This descriptive statistical survey was conducted at the end of the CMIE 1022 module in May 2012 during the entrepreneurship carnival. There were 217 first year medical and 40 nursing students of session 2011/2012 and a total of 177 responded to the survey. The data were obtained from Course Evaluation Form prepared by CESMED. The questionnaires were answered anonymously. The questions that were selected for this study were: "This course has increase my soft skills", "This course has change my awareness towards entrepreneurship", "This course has increase my interest in entrepreneurship", "I have applied entrepreneurship into my own course”, "Fellows' performance in teaching and learning of CMIE 1022", "Should UKM students enrol into entrepreneurship course?”. These questions were marked using Likert scale (Strongly Agree, Agree, Average, Disagree, and Strongly Disagree). Another question selected was whether the students will take follow-up course in entrepreneurship in the following years in the university. Data were collected and analysed using SPSS Version 20. UKM Action and Strategic Grant PTS-2012-084 was used for this study.

\section{Result}

Table 1 shows the students' perception towards CMIE 1022 entrepreneurship course. Approximately $97 \%$ of the students disagree to enroll in the follow-up entrepreneurship course. 
Table 1: Students’ perception towards CMIE 1022 entrepreneurship course

\begin{tabular}{llllll}
$\begin{array}{l}\text { Increase My } \\
\text { Soft Skills } \\
(\%)\end{array}$ & $\begin{array}{l}\text { Change Awareness } \\
\text { Towards } \\
\text { Entrepreneurship } \\
(\%)\end{array}$ & $\begin{array}{l}\text { Interest In } \\
\text { Entrepreneurship } \\
(\%)\end{array}$ & $\begin{array}{l}\text { Application of } \\
\text { Entrepreneurship } \\
\text { Into Own Course } \\
(\%)\end{array}$ & $\begin{array}{l}\text { Fellow } \\
\text { Performance in } \\
\text { Teaching } \\
\text { CMIE 1022 } \\
(\%)\end{array}$ & $\begin{array}{l}\text { Should UKM } \\
\text { Students Enrol Into } \\
\text { Entrepreneurship } \\
\text { Course? (\%) }\end{array}$ \\
\hline 13.3 & 33.2 & 44.8 & 42.7 & 2.4 & 43.7 \\
36.4 & 32.0 & 29.6 & 35.1 & 20.8 & 37.9 \\
50.3 & 37.8 & 25.6 & 22.2 & 76.8 & 18.4 \\
\hline
\end{tabular}

\section{Discussion}

From the survey, $50.3 \%$ of the students responded that their soft skills have increased. The soft skills involved were leadership, teamwork and communication skills. In this module, all students were divided into a group of 5 people which will represent a company. Each group has given the task to design and promote two Bluetooth headsets, of which one was highend and the other was low-end. They also have to organize themselves in a company. Using the online teaching materials that they have gone through, they had to come out with a business plan for promoting the headsets. With all these exercises, their leadership, teamwork and communication skills do increase.

Thirty-seven point eight percent of the students agreed that the course has increased their awareness about entrepreneurship while 25.6\% agreed that they developed interest in entrepreneurship after going through this course. These results may be related to less exposure of any branch of entrepreneurship i.e. financial and marketing as medical and nursing students were in science stream which mainly did not include any of these subjects in their secondary schools. Only $22.22 \%$ of the students will apply the knowledge that they gain from the entrepreneurship course into their own course. This is because the medical and nursing curriculum are mainly focusing on medicine and nursing. These students also felt that there would not be any benefit of using the knowledge during their medical and nursing education years. This is also supported by Rhodes where the author stated that it is unusual for a physician to receive training in economics and finance (5).

As highlighted earlier, the lecturers in the Faculty of Medicine with the assistance of teaching assistants from Faculty of Economics and Management were appointed as the fellow of CESMED in conducting this course. Seventy-six point eight percent of the students agreed that the teaching of CMIE 1022 was acceptable. Despite that, $43.7 \%$ of the students disagreed that this course should be taken by all students of UKM. This is because each degree programme in UKM has different learning outcomes compared to CMIE 1022, thus making CMIE 1022 module to be burdensome to non-business degree students. Some students also highlighted that being doctors and nurses, their aim was to treat and help people and not to earn profit or into business.

In contrast, few authors have highlighted the importance of entrepreneurial skills among healthcare providers including doctors and nurses. As the technology progress and become more sophisticated, traditional way of life has been discarded. Wahome et al has highlighted that for Malaysia to be a developed nation and a high-income nation by 2020, drastic changes especially in education, science and agriculture need to be engaged especially in entrepreneurship and innovative skills among its people (2). Therefore, joint venture for example with New York Academy of Sciences as well as with Stevens Institute of Technology can help Malaysia as a whole to achieve its target to have knowledge-based and innovative economy. UKM has taken the first action to incorporate 
entrepreneurship teaching course into the undergraduate programme and become a compulsory subject to all first year undergraduate. What makes it even more unique is the introduction of entrepreneurship into the health cluster, namely medicine, nursing, dentistry, health sciences and pharmacy students.

Rhodes supported that entrepreneurship course which include innovation will benefit medical students. The author stated that the traditional public health system need to be shifted from 'hierarchical network system' to a 'decentralized network system', as it will further support the public health and public finance authorities in order to create more constructive era of sector governance (5). Wahome et al also suggested that there has to be an important role to create and administer new programmes to promote mentoring and entrepreneurship, sharing best practice for higher education reform, coordinating research as well as universityindustry research opportunities (2).

Toner et al also stated that the current healthcare system are now very complex with increasing problems of aging residents, increase of noncommutable diseases, cancer, obesity, rising costs, regulatory intervention and increasing responsibilities in patient safety (6). Thus the authors suggested introducing invention, innovation and entrepreneurship skills into academic medical centres. These will compliment the vast role of academic medical centres of not only taking care of patients but also to improve healthcare by bridging these innovation to the bedside. They also suggested that the process needs to be properly incorporated into the educational syllabus of medical schools.

Implementation of CMIE 1022 is not without its flaws. Nevertheless, as this is the first cohort of its kind in Malaysia, further improvement can be made to tailor-made the syllabus to suits Malaysian education system, producing more talented, skilled and creative healthcare professional to serve the population.

\section{Conclusion}

It can be concluded that CMIE 1022 has indeed increased students' soft skills especially in teamwork, leadership and communication skills. It also generally have achieved some of its goal for the students to be more aware of entrepreneurial and innovation skills in life as future doctors. With further improvement of the CMIE 1022 syllabus, more objectives can be fulfilled.

\section{Reference}

1. Webfinance. Entrepreneurship. 2012. [cited 1 October 2012] http://www.businessdictionary.com/definitio n/entrepreneurship.html

2. Wahome M., Rubinstein E. Malaysia Collaborates with the New York Academy of Sciences to develop an innovation-based economy. Malaysian J Med Sci. 2011; JulSep: 18(3): 1-3

3. Malaysian Qualifications Agency. (2011). Malaysian qualifications framework: point of reference and joint understanding of higher education qualifications in Malaysia. 2011. [Cited 1 October 2012]. Available from:

http://www.mqa.gov.my/portal2012/dokume n/MALAYSIAN\%20

QUALIFICATIONS\%20FRAMEWORK_2 011.pdf

4. Sivaselvam S. Entrepreneurship and innovation: changing mindset is the priority for UKM. 2012. [Cited 1 October 2012]. Available from: http://pkukmweb.ukm.my/news/index.php/e n/extras/942-entrepreneurship-andinnovation-changing-mindset-is-the-priorityfor-ukm-.html

5. Rhodes G. The medical mandala: the public health benefits of entrepreneurship tools and skills among medical students in India. Indian Journal of Public Health. 2012; AprJun: 56(2): 105-109

6. Toner M., Tompkins RG. Invention, innovation, entrepreneurship in academic medical centers. Surgery. 2008;143(2): 168171 